\title{
Integrated Management of Bulb Rot (Fusarium proliferatum) of Garlic (Allium sativum L.)
}

\author{
Avinash Patil*, Sobita Simon and Girish Patil \\ Department of Plant Pathology, Naini Agricultural Institute, Sam Higginbottom University of \\ Agriculture, Technology and Sciences, Prayagraj - 211007 (U.P.), India \\ *Corresponding author
}

Keywords

Fungicide,

Fusarium

proliferatum, garlic, neem cake,organic amendments

Article Info

\section{Accepted:}

14 May 2020

Available Online:

10 June 2020

\section{A B S T R A C T}

Garlic (Allium sativum L.) is the second most widely used Allium next to onion belonging to the family Amaryllidaceae. Garlic crop is affected by several fungal, bacterial and viral diseases, of which, bulb rot is caused by Fusarium proliferatum. Damage caused by this pathogen can causes $45 \%$ yield losses. The research was carried out for the management of bulb rot using organic amendments. Five organic amendments and a fungicide (treated check) were evaluated for their efficacy under in vitro and in vivo against bulb rot of garlic incited by Fusarium proliferatum, Carbendazim @ $0.1 \%$ as treated control was effective in the inhibition of mycelial growth (100\%) of $F$. proliferatum followed by T3(Neem cake-46.98\%), T5(Mustard cake-44.72\%), T1(Vermicompost-37.68\%), T2(FYM-34.29\%), T4(Poultry manure$28.89 \%$ ). The organic amendments and a fungicide (treated check) were tested against bulb rot under field conditions during Rabi 2017-2018. Among all the treatments, soil drenching with carbendazim @ 2g/lit (Treated check) was found most effective in the reduction of disease incidence followed by Neem cake, Vermicompost, FYM, Mustard cake and Poultry manure as compared to untreated check. The maximum yield was recorded in (FYM-51q/ha). The maximum number of cloves and bulb weight was recorded in FYM and bulb size was maximum in vermicompost.

\section{Introduction}

Garlic (Allium sativum L.) is the second most important bulb vegetable after onion and it is grown worldwide in all temperate to subtropical areas as an important spice and medicinal plant (Rabinowitch and Currah, 2002). The origin of garlic is in Central Asia, but cultivated all over the world, in India, Spain, France, Egypt, Bulgaria, Hungary,
USA, Mexico and Brazil. Garlic is one of the important bulb crops grown and used as a spice or condiment throughout India. It is also important foreign exchange earner for India.

Garlic has higher nutritive value as compared to other bulbous crops. It is a rich source of carbohydrates (29\%), proteins $(6.3 \%)$, minerals $(0.3 \%)$ and essential oils (0.1-0.4\%) and also contains fat, vitamin $\mathrm{C}$ and sulphur 
(Memane et al., 2008). In addition to this garlic has several medicinal values. It has antibacterial, antifungal, antiviral and antiprotozol properties. It is beneficial to cardiovascular and immune system and has antioxidant and anticancer properties (Harris et al., 2001).

In India about $35-40 \%$ losses estimated to be lost as post-harvest losses during handling and storage. Fusarium spp. is widely distributed in the world and is among soilborne fungi that attack garlic and onion. Damage caused by this pathogen can produce 45\% less yield (Schwartz and Mohan, 1995).

\section{Materials and Methods}

The experiment was conducted in the research laboratory and Department of Plant Pathology and Central Research Farm, Sam Higginbottom University of Agriculture, Technology and Sciences, Allahabad. The experiment was laid out Randomize Block Design with three replications. Organic amendments were used to minimize the disease. Local variety of garlic was selected for the experiment.

Neem cake $(500 \mathrm{~kg} / \mathrm{ha})$, Mustard cake (500 kg/ha), FYM (10t/ha), Vermicompost (5t/ha), Poultry manure (5t/ha) and Carbendazim $(2 \mathrm{gm} / \mathrm{lit})$ as treated check were used to minimize the disease. Observations were recorded on Disease incidence $(\%)$ at 60,75 and 90 DAS, plant height and number of leaves at 60, 75 and 90 DAS, bulb size, number of cloves, bulb weight at harvest and Yield (q/ha).

Disease incidence (\%) was calculated by the following formula,

$$
\text { Disease incidence }(\%)=\frac{\text { Total number of plants infected }}{\text { Total number of plant observed }} \times 100
$$

\section{Poisoned food technique}

The extracts of different organic amendments viz., Neem cake, Mustard cake, FYM, Poultry manure, Vermicompost, were prepared by suspending $30 \mathrm{~g}$ of each organic material in $150 \mathrm{ml}$ sterile distilled water in flask and left for 25 days. The flasks were shaken on alternate day for thorough mixing and dissolution of the content.

After 25 days, the flasks were thoroughly shaken and content were filtered through double layered muslin cloth and autoclaved at $15 \mathrm{lbs}$ pressure for 20 minutes. The sterile extracts were used for testing their inhibitory effect on Fusarium proliferatum in vitro by poisoned food technique. The autoclaved extracts were individually added in previously sterilized melted and cooled potato dextrose agar medium @10 per cent v/v at the time of pouring in Petri plates and mixed thoroughly.

All the plates were incubated at room temperature at $\left(27+2^{\circ} \mathrm{C}\right)$ after placing the 5 $\mathrm{mm}$ disc of actively growing 10 days old pure culture of Fusarium proliferatum. Four repetitions were kept for each treatment. Medium without organic extract served as control. The radial growth of the test organism and pathogen was measured after 10 days and the per cent inhibition was calculated as per the following formulae suggested (Yelmame et al., 2010).

The percent inhibition of mycelia growth over control was derived by the following formula:

Growth inhibition $(\%)=\frac{\mathrm{dc}-\mathrm{dt}}{\mathrm{dc}} \times 100$

where, dc- diameter of colony in control. dt- diameter of colony in treatment (Amadioha, 2003). 


\section{Results and Discussion}

\section{In-vivo efficacy of organic amendments}

It is evident from the data that all the organic amendment tested reduced bulb rot incidence of garlic significantly over control. Neem cake was found significantly superior over all other treatments resulted maximum disease control, $\mathrm{T}_{3}($ Neem cake-19.84\%) followed by $\mathrm{T}_{1}$ (Vermicompost-20.92\%), $\quad \mathrm{T}_{2}$ (FYM22.54\%), $\mathrm{T}_{5}$ (Mustard cake-22.97\%) and $\mathrm{T}_{4}$ (Poultry manure-27.92\%). The probable reason for such findings may be the suppressive ability of neem organic amendment in inhibiting growth of soil borne pathogens has been demonstrated to be through competition, antibiosis or due to increase of soil microbial populations. The similar finding is report by Goudar and Kulkarni (1998), where they noticed minimum disease incidence using neem cake, Kimaru, et al., (2004), who conducted both in the laboratory and greenhouse conditions to investigate the effects of Neem Kernel cake powder (NKCP) on growth, sporulation and pathogenicity of tomato wilt caused by Fusarium oxysporum f. sp. lycopersici and in both the condition Neem cake was found significantly effective.

The maximum yield was found in $\mathrm{T}_{2}$ (FYM$51 \mathrm{q} / \mathrm{ha})$, followed by $\mathrm{T}_{1}$ (Vermicompost47.66), $\quad \mathrm{T}_{3}$ (Neem cake-40), $\quad \mathrm{T}_{4}$ (Poultry manure-39.16), and $\mathrm{T}_{5}$ (Mustard cake-32.5) and $\mathrm{T}_{6}($ Carbendazim-23.5) as compared with untreated $\mathrm{T}_{0}$ (Control-20.42) The maximum number of cloves and bulb weight was found in FYM, were bulb size was found in vermicompost. Amendment of organic matter in soil or horticultural container medium with either compost or vermicompost is essential to improve the soil physical, chemical and biological properties which subsequently enhance plant growth substantially. The enhanced nutrient uptake by plants, action of the HA fractions, and PGRs. (Brinchi et al., 2010).

Table.1 Effect of organic amendments on bulb rot (Fusarium proliferatum) of garlic

\begin{tabular}{|c|c|c|c|c|c|c|c|c|}
\hline \multicolumn{2}{|c|}{ Treatments } & \multicolumn{3}{|c|}{$\begin{array}{l}\text { Percentage of Disease } \\
\text { incidence }\end{array}$} & \multicolumn{3}{|c|}{$\begin{array}{l}\text { Avg. Dia. of pathogen } \\
\text { (cm) }\end{array}$} & \multirow{3}{*}{$\begin{array}{l}\text { Mycelia growth } \\
\text { inhibition }(\%) \\
\text { over control at } \\
120 \text { hrs } \\
\qquad 0.00\end{array}$} \\
\hline & & \multirow{2}{*}{$\begin{array}{r}30 \text { DAS } \\
19.05\end{array}$} & \multirow{2}{*}{$\begin{array}{r}\text { 60DAS } \\
27.49\end{array}$} & \multirow{2}{*}{$\begin{array}{l}\text { 90DAS } \\
36.12\end{array}$} & \multirow{2}{*}{$\begin{array}{r}24 \mathrm{hr} \\
2.45\end{array}$} & \multirow{2}{*}{$\begin{array}{r}72 \mathrm{hr} \\
4.9\end{array}$} & \multirow{2}{*}{$\begin{array}{r}\text { 120hr } \\
7.96\end{array}$} & \\
\hline $\mathbf{T}_{0}$ & Control & & & & & & & \\
\hline $\mathbf{T}_{1}$ & Vermicompost & 10.25 & 14.72 & 20.92 & 1.26 & 2.15 & 4.96 & 37.68 \\
\hline $\mathbf{T}_{2}$ & F.Y.M. & 11.65 & 15.83 & 22.54 & 1.35 & 2.55 & 5.23 & 34.29 \\
\hline $\mathbf{T}_{3}$ & Neem cake & 8.02 & 14.60 & 19.84 & 1.05 & 1.95 & 4.22 & 46.98 \\
\hline $\mathbf{T}_{4}$ & $\begin{array}{l}\text { Poultry } \\
\text { manure }\end{array}$ & 13.16 & 19.39 & 27.92 & 1.48 & 3.05 & 5.66 & 28.89 \\
\hline $\mathbf{T}_{\mathbf{5}}$ & Mustard cake & 11.67 & 17.55 & 22.97 & 1.15 & 2.05 & 4.40 & 44.72 \\
\hline \multirow[t]{3}{*}{$\mathbf{T}_{6}$} & Carbendazim & 6.27 & 12.88 & 13.26 & 0.00 & 0.00 & 0.00 & 100 \\
\hline & C.D. $(5 \%)$ & 3.45 & 2.67 & 4.66 & \multicolumn{3}{|c|}{0.40} & \\
\hline & S. Ed ( $( \pm)$ & 1.77 & 1.06 & 3.23 & \multicolumn{3}{|c|}{0.02} & \\
\hline
\end{tabular}


Table.2 Effect of organic amendments on growth parameters of garlic

\begin{tabular}{|l|l|c|c|c|c|}
\hline \multicolumn{2}{|c|}{ Treatments } & Bulb weight & Bulb size & $\begin{array}{c}\text { Number of } \\
\text { cloves }\end{array}$ & $\begin{array}{l}\text { Yield } \\
\text { (q/ha) }\end{array}$ \\
\hline $\mathbf{T}_{\mathbf{0}}$ & Control & 19.03 & 2.23 & 11.92 & 20.42 \\
\hline $\mathbf{T}_{\mathbf{1}}$ & Vermicompost & 28.42 & 3.76 & 21.13 & 47.66 \\
\hline $\mathbf{T}_{\mathbf{2}}$ & F.Y.M. & 31.10 & 3.66 & 22.40 & 51 \\
\hline $\mathbf{T}_{\mathbf{3}}$ & Neem cake & 24.59 & 3.13 & 19.73 & 40 \\
\hline $\mathbf{T}_{\mathbf{4}}$ & Poultry manure & 22.37 & 3.06 & 19.13 & 39.16 \\
\hline $\mathbf{T}_{\mathbf{5}}$ & Mustard cake & 22.10 & 2.86 & 18.13 & 32.5 \\
\hline $\mathbf{T}_{\mathbf{6}}$ & Carbendazim & 19.65 & 2.63 & 15.86 & 23.5 \\
\hline & C.D.(5\%) & $\mathbf{2 . 1 8}$ & $\mathbf{0 . 1 8}$ & $\mathbf{0 . 7 8}$ & \\
\hline & S. Ed ( $\mathbf{( )}$ & $\mathbf{1 . 7 8}$ & $\mathbf{0 . 0 0 5}$ & $\mathbf{0 . 0 9}$ & \\
\hline & & & & & \\
\hline
\end{tabular}

\section{In-vitro efficacy of organic amendments}

All the organic amendments significantly inhibit the mycelia growth of $F$. proliferatum. Maximum inhibition of mycelial growth of $F$. proliferatum was observed in $\mathrm{T}_{3}$ (Neem cake- $46.98 \%$ ) followed by $\mathrm{T}_{5}$ (Mustard cake44.72\%), T1 (Vermicompost-37.68\%), $\mathrm{T}_{2}$ (FYM-34.29\%), $\mathrm{T}_{4}$ (poultry manure-28.89\%). Our observations are conformity to Yelmame et al., (2010), were tested the extracts of different organics of Neem cake, Mustard cake, FYM, Groundnut cake, Poultry manure, Press mud, Castor cake and coconut cake against Fusarium solani caused wilt of chilli in in vitro.

Minimum growth of pathogen was recorded in the extracts of Neem cake showing excellent inhibitory effect $(59.8 \%)$ followed by Mustard cake (52.61\%). Nikam et al., (2007), tested various oilseed cakes viz., Groundnut cake, Cotton seed cake, Neem cake and Castor seed cake. Amongst four oil cakes tested Groundnut cake is proved to be effective against $F$. oxysporum f.sp. ciceri followed by Neem cake and Castor cake.

From present study, it was concluded that neem cake@ 500kg and FYM @10t/ha were found as best treatment to minimize bulb rot disease of garlic where as in lab experiment neem cake and mustard cake were found to be most effective. Since chemicals have many hazardous effects on the environment as well as on the person who handles it while application in the field and consumers using the product, used of organic amendments in field condition would be considered as better, as it is beneficial and eco-friendly. Since, one year data is not sufficient to conclude concurrent result, further experimentations are required to confirm the results.

\section{References}

Amadioha, A. C. (2003). Evaluation of some plant extracts against Colletotrichum lindethuthianum in cow pea. Acta Phapathological Entomological Hungariun. 38(3/4): 256-259.

Borude, D. and Fatima, S. (2017). Studies on market diseases of garlic (Allium sativum 1) Epitome: international journal of multidisciplinary research. Vol. III, Issue V. ISSN: 2395-6968.

Brinchi, K., Pratibha S., Susheel P., Harikesh S. (2010). Vermicompost as modulator of plant growth and disease suppression. Global science book. 58-66.

Etoh, T. and Simon, P. W. (2002). Diversity, fertility and seed production of garlic. 
In:Rabinowitch, H. D. and L.Currah (Eds.). Allium crop science: Recent advances. $\quad C A B \quad$ International, Wallingford, UK. pp. 101-117.

Farooqui, A. A., Sreeramu, B. S. and Srinivasappa, K. N. (2005). Cultivation of spice crops. Universities press (India), Private limited Hyderguda, Hyderabad, pp 457.

Goudar, S. B. and Kulkarni, S., (1998) Effect of organic amendments on Fusarium udam Butler- the causal agent of wilt of pigeonpea. Karnataka Journal of Agricultural Science, 11(3): 690-692.

Harris, J. C., Cottrell, S. L., Plummer, S. and Lloyd, D. (2001). Antimicrobial Properties of Allium sativum L. (garlic). Applied Microbiology and Biotechnology. 57: 282-286.

Kamenetsky, R. and Rabinowitch, H. D. (2001). Floral development in bolting garlic. Sexual Reproduction. (4): 235241.

Kimaru S.K., Waudo S.W., Manda E., Seif A.A., Birgen J.K. (2004) Effect of Neem Kernel Cake Powder (NKCP) on wilt of tomato when used as soil amendment. Journal of Agriculture and Rural Development in the Tropics and Subtropics. 105(1): 31-33.

Memane, P. G., Tomar, R. S., Kakade, D. K., Kulkarni, G. U. and Covatia, R. S. (2008). Effect of clove weight and plant growth regulators on growth and yield of garlic (Allium sativum L.) cv GG 3 . The Asian Journal of Horticulture. 3(1): 82-86.

Nikam P. S., Jagtap J. P., Sontakke P. L.(2007) Management of chickpea wilt caused by Fusarium oxysporum f.sp. ciceri. African Journal of Agricultural Research. 2(12):692-697.

Rabinowitch, H.D and Currah, L. (2002) Allium crop Science: Recent advances. CAB International. Rai, $\mathrm{N}$ and Yadav, D.S (2004) Advances in vegetable production. Researchco book centre, Karol Bagh, New Delhi. 995pp.

Rahim, M. A. and Fordham, R. (1994). Control of bulbing in garlic. Acta Horticulture 358: 369-374.

Schwartz, H. F. and Mohan, K. (1995). Compendium of onion and garlic diseases. Academic Press. San Diego California. p. 54.

Tindall, H.D. (1986) . Vegetables in the tropics. Mc Millan Education Limited Houdmills, Basintoke Hamshire England. pp-533.

Yelmame, M. G., Mehta, B. P., Deshmukh, A. J. and Patil, V. A. (2010). Evaluation of some Organic extracts in In vitro to control Fusarium solani causing Chilli Wilt. International Journal of Pharma and Bio Sciences. 1(2):19-20.

\section{How to cite this article:}

Avinash Patil, Sobita Simon and Girish Patil. 2020. Integrated Management of Bulb Rot (Fusarium proliferatum) of Garlic (Allium sativum L.). Int.J.Curr.Microbiol.App.Sci. 9(06): 176-180. doi: https://doi.org/10.20546/ijcmas.2020.906.023 